\title{
Personhood and the Cosmos: Exploring Some Similarities Between Traditional African and Western Conceptions of Personhood
}

\author{
Makotoka Kahaka \\ Languages and Social Sciences Education, Faculty of Education, University of Botswana, Private Bag 0022
}

\begin{abstract}
The African conceptions of personhood are generally viewed to stand in contrast to the conceptions of personhood that have dominated western philosophy. There is a general consensus that on the whole, the African view holds a communal understanding of personhood where relationships and communal existence defines a person. This is in contrast with the Western view where a personhood is understood in individualistic terms and almost totally outside the group. Notwithstanding this plausible contrast, this article submits that an analysis of the views of some classical and traditional African and Western philosophical views on the nature of relationship between human persons and the rest of nature suggest a favourable comparison of views between the two camps. Thus, both these traditional African and the Western views on personhood and reality put emphasis on the interrelatedness or interconnectedness of human person and everything in nature. This demonstrates that with respect to the specific African and Western traditional views discussed and compared in this work, there is a degree to which some of their conceptions of personhood can be harmonized.
\end{abstract}

Keywords: Personhood, cosmos, African view, Western view, Contrasting view, similar view

DOI: $10.7176 / \mathrm{JPCR} / 47-04$

Publication date: December $31^{\text {st }} 2019$

\section{Introduction}

The concept of personhood is considered to be one of the most reoccurring problems in philosophy. Early Greek philosophers such as Socrates, Aristotle and later prominent modern western philosophers like Rene Descartes and John Locke were preoccupied with the concept of personhood. During colonial and in post-colonial times, some African scholars such as Placide Tempels, John Mbiti, Kwame Gyekye, Chukwudum Okolo, Kwasi Wiredu and many others likewise have shown a lot of interest in this and other closely related concepts such as self, human being and individuality. The aim of some of these African scholars was to define what is often referred to as 'an African understanding' of personhood (and other phenomena) and distinguish it from 'a western understanding'. However, defining personhood has always been a controversial, sometimes even an elusive task, and yet it remains a very necessary and unavoidable endeavour particularly in philosophy. This is primarily because personhood is closely tied to all spheres of human existence, including moral, legal, political and social concepts of identity, responsibilities, privileges, rights, citizenship, equality, liberty and so on. Personhood continues to be a topic of much debate where critical questions regarding issues of abortion and foetal or reproductive rights, as well as animal rights have been asked. Further, notions of personhood have also generated debates about corporate personhood and the beginning of human personhood among ethical questions.

It has been argued that the process through which personhood is recognized varies across cultures, and this on its own implies that notions of personhood are not universally applicable. For instance, Shweder and Bourne (1984) discuss the variances between Melanesian personhood and Western personhood in terms of sociocentric and egocentric persons respectively (1984: 127-8; Mageo 1995: 283). Smith (2012: 50) observes that in other contexts, the Japanese have been characterized as 'groupist' in contradistinction to Westerners who are characterized as 'individualistic'. Similarly, some Africans have been characterized as subscribing to communitarian/social personhood by which "personhood is a standing or status that is bestowed upon one human being, by others, in the context of a relationship and social being", (Kitwood, 1997: 8). What this shows is that it is a people's concept of personhood that determines the way they acknowledge, understand and relate to each other. Thus, individuals may not always consider other human beings as persons because determining what or who is a person involves such boundaries and criteria that may not be satisfied by others. These boundaries and criteria are not universally applicable; they vary cross-culturally where factors such as gender, morality, ethnicity, age, social and economic status come into play. Where someone falls in relation to those boundaries and criteria will determine whether she/he is considered and treated as a person. Moreover, some views place strong emphasis on the essential interconnectedness or interrelationship between human persons and the rest of nature, and provide this as grounds for not only understanding the true nature of personhood, but also for having moral obligation towards nature (Behrens, 2010). Based on this interconnectedness, there is a view that there is no difference in terms of the essential or metaphysical nature of human persons, the natural environment and the whole reality or cosmos. That is, nature and the cosmos as whole is on the same moral threshold as human 
persons, as a result, it necessitate that the two should be accorded the same moral significance and treatment. The idea that there is an interplay and interdependence between the essential nature of personhood and the whole of reality forms the foundation of the differences of opinions between the African and Western conceptions of personhood. The understanding is that on the whole, Western conceptions of personhood holds an individualistic view of a person divorced from the rest of reality, while its African counterpart holds a communitarian or relational view of personhood where there is interrelationship not only between individuals, but also between human persons and the rest of nature. Notwithstanding this plausible contrast, it will be demonstrated that an analysis of the views of some classical and traditional African and Western views on the nature of relationship between human persons and the rest of nature suggest a favourable comparison of views between the two camps. However, before this view is expounded, the distinction between the African and Western traditional views on personhood is discussed further in what follows below.

\section{Contrasting the African and Western traditional views on personhood}

The view that traditional western philosophy is individualistic in its approach to personhood and human relations is articulated by many modern scholars including Wilkinson (2002). In her discussion of how cultural differences between races influence perceptions on gender in South Africa, and Wilkinson (2002:355) writes;

White South Africans owe their heritage to the world-view that has been inherited from the Greeks, influenced by Cartesian dualism, Kantian rationalism, and the resultant liberalist values of individualism....the overriding ethos is that of Western individualism.

The view expressed above adds to the general position that traditional Western philosophy, in contradistinction to traditional African view, holds that the human person has an independent existence and should be treated as an individual. Likewise, Okolo (2002) points out that in the African metaphysics (as opposed to its traditional Western counterpart) the self is almost totally viewed from 'outside', in relation to others, and not from the 'inside' in relation to itself. According to some authors on this African perspective, the Western view of the person has resulted in notions of individual rights where the rights and welfare of the individual are placed above those of the community. In connection to this view, Dube (2006: 134), made an observation regarding Botswana's HIV and AIDS testing policy, pointing out that the policy was based on Western individualistic values of confidentiality and private individual rights. This practice, according to Dube, overlooked the society around the individual and has placed the individual over and above the community that has made him/her a person, which is very inconsistent with the African communitarian understanding of a person. Dube believes that the individual's rights are in this case emphasized at the expense of the community rights because the individual who does not want to test for HIV and AIDS cannot be forced to, meanwhile such individual may continue to spread the virus in the event that he or she is positive and does not see the value of not spreading the virus further. Hence, according to the African view of person, which is basically communitarian, the individual does not come before the community, it is the community that gives the individual his being and personhood (Menkiti 1984); Okolo 2002; and Wilkinson 2002). When discussing this African view in contrast with the Western view, Okolo (2002: 213) puts it this way: 'It is the community which makes the individual, to the extent that without the community, the individual has no existence'. This is easily contrasted with the Western traditional thought which starting point in understanding personhood is based on the concept of an 'unconstrained and uncontextualised' self and its inner being (Mudimbe, 1988). In the words of Mbiti, an individual in the African context is defined as, 'I am because we are and since we are, therefore I am', (Mbiti 1969:108). This position by Mbiti is considered to be not only an adaptation of Rene Descartes' cogito ergo sum (I think, therefore I am), but also a demonstration of the dissimilarity in ideas that exist between the African and the Western understanding of a person. While the African societies understand that a person is only a person provided he/she is a member not only of the community, family, and clan but also of the living dead (ancestors), plants and animals (Mbiti 1969), the Western societies mostly understand a person as some 'isolated static quality of rationality, will or memory', (Menkiti 1984: 172). Thus Western philosophy have been accused by some scholars such as Menkiti (1984) of erroneously reducing a person to one entity or another. Not only has Western philosophy been accused of conceiving the idea of an individual that is capable of existing by itself, but also of ignoring the inseparable connection that exists between persons and all living and non-living beings. This Western conception of personhood is in contradistinction to its African counterpart which is considered to be more inclusive and interconnected with the whole of reality. One of the description of the Western view on personhood as contrasted with the African view is given by Tempels (1959: 103) below;

Just as Bantu (Black African) ontology is opposed to the European of individuated things existing in themselves, isolated from others, so Bantu psychology cannot conceive of a man as an individual, as a force existing by itself and apart from its ontological relationship with other living beings and from its connection with animals or inanimate forces around it.

Notwithstanding this plausible contrast, a comparison of some traditional African and Western accounts of personhood brings out some interesting similarities between the two camps. It appears that there has been more 
emphasis on the contrast between the African and Western views on the notion of personhood, with very few works highlighting the similarity that exist between them. Therefore, this article will put premium on shared features based on the similarities that can be identified between some traditional African and Western views on personhood, without denying the difference that may exist between them. The discussion does not adopt a chronological order in its approach in terms of time the particular African and ancient/classical Western philosophers did their contribution to area under discussion, but focuses rather on areas of similarity between the two philosophical perspectives. The discussion that follows aims to demonstrate that in principle, there are more similarity between the proponents of the two viewpoints in question in their conceptions of personhood.

\section{Comparing of some traditional African and Western views of personhood}

Through his Bantu Philosophy (1959), Placide Tempels made an attempt to outline what he believed to be the African view of reality and human persons in relation to the whole of reality (cosmos), as well as what a person is in the African thought. According to Deacon (2002), Tempels' Bantu philosophy should be seen as an organized depiction of his understanding of the indigenous Congolese people which he achieved through his close relationship with them. However, it is clear that Tempels did not intend for his work to be a disclosure of the thought system underlying only the traditional indigenous people of Congo, but an accurate representation of world-view of all the African people (See for example Tempels 1959:21). Tempels points out that according to African thinking; the universe is ultimately controlled by God who possesses 'force' in himself and therefore gives force to everything he has created. He explains that Africans refer to God as Force the same way Christians refer to their God as Love, so that Force and God are almost inseparable, and a thought of God is a thought of Force. God used this same force to create everything that exists, and he went further to give force to everything. This means humans, animals, plants, rocks, etc are created with and contain vital force. Forces and their distributions are different, and necessarily so, so that there is a distinction between the forces of humans and the forces of objects. On this points Tempels explains that 'muntu', which means human, signifies '..vital force, endowed with intelligence and will...', while 'bintu', meaning objects and things, are '...forces not endowed with reason, not living' (Tempels 1959:55). Tempels' view can be likened to Plato's position that Likewise Aristotle, who is believed by some writers such as Ramose (2002: 1), to be the father of the definition 'man is a rational animal', had not immediately placed human beings in any distinguished position in relation to inanimate beings and animals. For Aristotle, the body is matter; a material substance that is found in all things, living and non-living (Trigg 1988: 29). The soul is the form of living or organized bodies, therefore the body cannot exist without the soul, and neither can the soul without the body, yet the two are not identical. It is interesting to note that Aristotle actually thought that the soul belongs to all living things or to all things that have organic bodies. Consistent with Tempels' view discussed above, Aristotle maintained that the only fundamental difference between humans and animals, which also account for the power of speech in humans, is the fact that human beings have reason. On this point Trigg (1988:29) observes, "The power of reason, which is as much a moral as an intellectual faculty, is what distinguishes the human from the animal, according to Aristotle". Aristotle believed that plants and animals have souls which are concerned about nutrition and appetites respectively, and the human soul in turn, "includes the nature of the plant and animals souls but in addition possesses the rational faculty" (Trigg 1988:29). Similarly, and writing from the African perspective of the person and reality, Tempels explains that the difference between human persons and other non-human beings is that God made the nonhuman forces for the purpose of serving or of being used by human beings to strengthen their human vital forces. The purpose for creation or the designated purpose of the different vital forces, not their essence, becomes the distinguishing factor between human beings and other created beings, placing human beings above all other things. This may mean that according to this African perspective, the person and the whole of creation are essentially and metaphysically the same, or interdependent, a view that is compatible with Aristotle's view described above. Rwandais philosopher Alexis Kagame, who claimed, among other things, that the Bantu understands a human being as a complete animal and a being endowed with intelligence (Kaphagawani 2004), is another case in hand that demonstrate similarity of thought between some of the traditional African and Western views on personhood. Consistent with both Aristotle and Tempels' views above, Kagame assert that the human person can only be differed from all other beings by the fact that she/he possesses reason or intellect, which is the principle of original activity (Masolo 1983: 453). As a result of humans' privileged status of being sole possessors of intelligence, claims Kagame, humanity in Bantu thought has always been placed at a central position in relation to the whole of reality, and it is the focus of the visible and invisible worlds. On this point, Masolo (1983) explains that according to the Bantu conception of personhood and reality as presented by Kagame, all beings are conceived based on their participation in the whole of reality. This participation, it is understood, is dependent on intelligence, a quality attributable only to humans. As a result, humans alone are capable of causing certain events, especially in the metaphysical spheres of magic and witchcraft. Thus the human person 'is the agent of all the activities of lower beings which become the only media of man's own activity,' (Masolo 1983: 453, 4). 
In addition to Aristotle, there were earlier ancient western philosophers who, in their understanding of the nature of personhood, picked one or two entities as the basic components that constitute personhood or human nature. As it has been discussed above, it is apparent that some African philosophers such as Placide Tempels used a similar approach in their endeavour to understand and present an African concept of personhood. The PreSocratic philosophers' evaluation of personhood was such that they identified the nature of the human person with what they believed was the nature of the world around them. And because of this approach to personhood, the question 'who am I?' was for these Pre-Socratic philosophers' a sub-issue of the main question 'what is everything?' (Hicks 2005: 36). This analysis of the Pre-Socratic understanding of the human person is also supported by a number of writers including Roger Trigg (1988), W.K.C Guthrie (1962) and Samuel E. Stumpf (1994) who assert that the first philosophers of the Greek world in the sixth century BC assumed that human nature was subject to the same explanation as that of the physical world. It therefore seems that the real question that occupied many of these ancient philosophers including Thales, Anaximenes, Heraclitus, and Pythagoras, and to which they gave varied answers, was 'what is the nature of everything, including humans?' For instance, while Thales believed that the whole of reality, including humans, was essentially water, which was the basic element that was permanent and enduring in all things, Anaximenes and Heraclitus on the other hand believed that the basic substance was air and fire respectively. Thus their concept of personhood is often considered to be monist because of their tendency to view personhood as essentially one with everything else, or the whole of reality as one. According to Hicks (2005), this understanding of personhood by the Pre-Socratics is enriching rather than reductionist because it brings the realization that as a person, I am not just me; I am one with the whole, with all that is. The result of this realization is a close sense of identity between the individual and the whole of reality. When discussing what he regarded as African view of ontology and the basis for axiology, Ikuenobe (2016) provides an interesting explanation of the African view of reality and personhood. Arguably, this explanation or account of the traditional African view of personhood by Ikuenobe is consistent with the PreSocratics approach described above. The underlying thinking here, to which Ikuenobe clearly subscribes, is that whatever concept of personhood, (or beauty and goodness in terms of the focus of his discussion) philosophers or communities hold is often founded upon their metaphysical outlook of the whole of reality. Thus according to Ikuenobe, the dominant ontological view in many African traditions, which view undoubtedly informs their conception of personhood, 'is that reality is a unity that aims toward balance and harmony' p.136. This ontological relationship, according to African thought, is characterized by an intimate, infinite bond between all created beings (Temples 1959: 28). And the same ontological relationship "implies that the connections that people have with one another, other creatures, and entities or things, involve efforts to maintain unity and harmony in reality" (Ikuenobe 2016: 136). Moreover, Guthrie (1962) explains that Thales of Miletus, an earlier Greek philosopher who lived before Aristotle, regarded the soul as a motive force, and that all things are full of gods (Guthrie 1962:67). The word 'gods' used here is later translated as souls or spirits. Thus Thales is said to have identified soul or life with the cause of motion (Guthrie 1962:65). According to a number of scholars on early Greek philosophy such as Stumpf (1994) and Guthrie (1962), Pythagoras and the Pythagoreans (ca. 525500 B.C), who are believed to have interpreted one of the old Greek sayings (also known as Symbola) that prohibited the eating of beans among Greeks, connected among other things the fact that the stems of beans were hollow throughout and unjointed, to the return of souls from beneath the earth. Beans were also said to be of a windy or breathy nature and hence full of the life-force: they contain the souls of the dead (Guthrie 1962: 184). The basic belief here, according to Guthrie (1962), was that beans and human beings had their origin from the same form of primal matter. There was, therefore, a strong connection between (physical) nature and the essence of human beings according to the Pythagoreans. This implies that according to the Pythagoreans, there was no difference, metaphysically speaking, between a person and a non-person (say an animal or plant), since they all come from the same life force and contain the same basic substance. Again this ancient Western views of reality and personhood compares well with some of the traditional African views such as the one expressed in Senghor argument that "the whole of the universe appears as an infinitely small, and at the same time an infinitely large, network of life forces which emanate from God and end in God, who is the source of life. It is He who vitalizes and devitalizes all other beings, all the other life forces. In addition, Anaximenes (ca. 585-528 B.C.E) believed that air is the basic substance found in all things (living and non-living), while Heraclitus (ca. $535-475$ B.C.E), another early Greek philosopher, argued that reality was an ever living fire found in inanimate and animate objects alike (Stumpf 1994:8). Similarly, Okolo (2002), when making reference to what he refers to as 'important work in African philosophy pioneered by Placide Tempels', writes; '....the visible universe contains in its descending hierarchy human being, animals, vegetables and minerals', which relate to and interact with each other, (Okolo 2002:211). Like Temples, Kagame appeals to the notion of force as the unifying factor among all beings, living and non-living. On this point Ukwamedua (2011:253/4) writes;

According to Kagame, all that there is must necessarily belong to one of the four categories and must be conceived not as a physical substance but as force. Man is a force; all things are forces including place and time, modalities. They are all also related to one another because they are forces and this 
relationship is vivid in their very names because if the determinative is removed, the stem Ntu remains and is constant in all of them.

In principle therefore, there is agreement between Kagame's account of traditional African view of personhood and reality and the western views outlined above. Moreover, Plato seemed to advocate for a view of personhood that is consistent with African and Western perspectives discussed above. Even though Plato conceived of the human soul as having three parts, namely reason, spirit and appetite, it is evident that he thought human beings share the two of the aspects of the soul, i.e. desire and appetite, with animals. This conclusion can be reached in view of the assertion by Trigg when he writes, "of a crucial distinction between reason and desire...Plato exalts the characteristically human possession of reason at the expense of the more animal parts of our nature" (Trigg 1988: 14). On a different note, Plato also thought that even social and political system of the society are inseparable from its metaphysical and moral reality. He took these to be indicative of the natural connection that exists between the individual and the larger community or state. He argued that the state could demonstrate the greatest virtue of them all, namely justice, only to the degree that the individual could demonstrate the same virtue. Emphasizing this argument by Plato, Stumpf (1994) points out that there is a structural and natural as well as logical relation between individuals and the state. One may hastily reject this evidence on the ground that Plato's discussion here is concerned with a political structure or connection between the individual and the state, rather than a connection between the individual, the community and cosmos. However, it is evident that Plato's understanding of the state is not limited to the ruling elite or to an equivalent of modern day government, but extends to the whole reality and social structure or what we may refer to as the community in modern usage. Stumpf explains further on this point, by indicating that according to Plato 'a state will reflect the kind of people the community has become'. Not only does the state reflect the actual nature and character of individuals that constitute it, but also that if one want to understand the nature of the individual person, he/she needs to analyse the nature of the state. On this point Plato wrote; 'We should begin by inquiring what justice means in a state. Then we can go on to look for its counterpart on a smaller scale in the individual', (Stumpf 1994:70). It appears that even though it is the individuals who form the state and society, it is the state (community) that is the 'yardstick' for the individuals' moral uprightness. The state, according to Plato, is man writ large. Moreover Stumpf points out that Plato believed that the state (the community) is a natural institution because it grows naturally from, and reflects human nature. This immediately brings to mind some aspects of both Tempels (1959) and Mbiti's (1969) accounts of African personhood where they emphasised that according to African thinking, a person simply does not exist alone or as an individual entity. He/she exists corporately, that is through other people and the community he/she is part of. Mbiti (1969), for instance, argues that in African traditional thought, a person is defined in relation to the household, family, kinship and community at large. The community is inclusive of both past generations, present community and posterity. And as already mentioned, Tempels (1959) widens the scope to include animals, plants and rocks. This therefore makes the individual to be not only part of the whole, but to naturally want to care for others and for the rest of creation. Both camps discussed above seems to hold the view that human persons are not only ontologically connected to nature and governed by the natural laws and elements that govern the whole of reality, but also that as a result of this connection, humans are naturally communal and interdependent with each other.

\section{Conclusion}

This article has attempted to demonstrate that while there is no denying that the traditional African view of personhood is generally communal in nature, and therefore easily contrasted with its Western counterpart which has been described as individualistic, the similarities that exist between the two need to be highlighted as well. That is, it is evident that similar to the African traditional views discussed above, some ancient Western philosophers held communal understanding of personhood and view reality. Therefore, there is a degree to which the two perspectives of personhood equally advocated for interrelatedness, interdependence and harmony between humanity, divinity, animate and inanimate beings, as well as the whole of reality. It is clear that both the traditional African and the Western philosophers compared above place such strong emphasis on the view that all things in the cosmos are not only interconnected but also that they are ontologically dependent on each other. This makes it imperative for human beings to live in harmony not only with each other, but in and with the whole of nature. This demonstrates that with respect to the specific African and Western traditional views discussed and compared in this work, there is a degree to which some of their conceptions of personhood can be harmonized.

\section{References}

Behrens, K. (2010). Exploring African holism with respect to the environment. Environmental Values, 19(4), pp. 465-484.

Deacon, M. (2002). The status of Father Tempels and ethnophilosophy in the discourse of African philosophy. In: P.H. Coetzee, and A.P.J. Roux, eds., Philosophy from Africa: A text with readings. Cape Town: Oxford 
University Press, pp. 97-111.

Descartes, R. (1986). Meditations on First philosophy, trans. R. Rubin. Claremont, CA, Arete Press.

Dube, W.M (2006), Andikara! Four Hearts joined Together: On Becoming Healing-Teachers of African Religion in HIV/AIDS Prevention. In: I.A.P. Phiri and S. Nadar, eds., African Women, Religion and Health, New York, Orbis Books.

Gyekye, K. (2002). Person and Community in African thought. In: P.H. Coetzee, and A.P.J. Roux, eds., Philosophy from Africa: A text with readings. Cape Town: Oxford University Press, pp. 297-312.

Guthrie, W.K.C (1962). A History of Greek Philosophy: The Earlier Presocratics and the Pythagoreans. Cambridge, Cambridge University Press.

Harrison-Barbet, A. (1990). Mastering Philosophy, London, Macmillan.

Hicks, P. (2005). One or two? A historical survey of an aspect of personhood. Evangelical Quarterly 77.1, pp. $35-45$.

Ikuenobe, P. (2016). Good and Beautiful: A Moral-Aesthetic View of Personhood in African Communal Traditions. Essays in Philosophy, 17(1), pp. 125-163.

John, L. (1979). An Essay Concerning human Understanding, edited by P.H. Nidditch. Oxford: Clarendon Press.

Kaphagawani, D. (2004). African Conceptions of a Person: A Critical Survey. In: K. Wiredu, ed., A Companion to African Philosophy; Malden, Mass.: Blackwell, pp. 332-342.

Kitwood, T. (1997). Dementia reconsidered: the person comes first. Open University Press.

Mageo, J.M (1995). The reconfiguring self. American Anthropologist. 97(2), pp.282-296.

Masolo, D.A. (1983). Alexis Kagame (1912-1981) and «La Philosophie Bantu-Rwandaise De L'etre». Africa: Rivista trimestrale di studi e documentazione dell'Istituto italiano per l'Africa e l'Oriente, 38(3), pp.449454.

Mbiti, J.S. (1969). African Religions and Philosophy. London: Heinemann Publishers.

Menkiti, I.A. (1984). Person and community in African traditional thought. In: R.A Wright, ed., African Philosophy: An Introduction. Washington: University Press of America, pp. 171-181.

Mmualefhe, O.D. (2007). Botho and HIV/AIDS: A Theological Reflection.: In J.B.R. Gaie and S.K. Mmolai eds., The concept of botho and HIV/AIDS in Botswana, Zapf Chancery, Eldoret, Kenya, pp 1-27.

Mosley, A. (1999). An Introduction to African Philosophy. Teaching Philosophy, 22(4), pp. 399-402.

Mudimbe, V.Y (1988). Liberty in African and Western Thought. Washingtong, DC; Institute for Independent Education.

Okolo, C.B. (2002). Self as a Problem in African Thought. In: P.H. Coetzee, and A.P.J. Roux, eds., Philosophy from Africa: A text with readings. Cape Town: Oxford University Press, pp. 209-218.

Ramose, M.B. (2002). The struggle for reason in Africa. In: P.H. Coetzee, and A.P.J. Roux, eds., Philosophy from Africa: A text with readings. Cape Town: Oxford University Press, pp. 1-8.

Senghor, L.S. (1995). Negritude: A Humanism of the Twentieth Century. In: F.L. Hord and J. Scott, eds., I Am Because We Are: Readings in Black Philosophy, eds., Amherst, MA, University of Massachusetts Press, pp. 45-54.

Shweder, R.A. and Bourne, L. (1984). Does the concept of a person vary cross-culturally? In: RA. Shweder \& RA. LeVine. eds., Culture theory: Essays on mind, self, and emotion. New York: Cambridge University Press, Pp. 158-199.

Smith, K. (2012). From dividual and individual selves to porous subjects. The Australian Journal of Anthropology, 23(1), pp. 50-64.

Stumpf, E.S. (1994). Philosophy: History and problems. New York: McGraw-Hill, Inc. USA.

Tempels, R.P. (1959). Bantu Philosophy. Paris: Presence Africaine.

Trigg, R. (1988). Ideas of Human Nature: An Historical Introduction. Oxford: Blackwell Publishers.

Ukwamedua, N.U. (2011). A Critical Review of Alexis Kagame's Four Categories of African Philosophy, Ogirisi: a new journal of African studies Vol. 8, pp. 248-265.

Wilkinson, J.R. (2002). South African Women and the Ties that Bind. In: P.H. Coetzee, and A.P.J. Roux, eds., Philosophy from Africa: A text with readings. Cape Town: Oxford University Press, pp. 343-360.

Wiredu, K. (2002). On decolonizing African Religion, In: P.H. Coetzee, and A.P.J. Roux, eds., Philosophy from Africa: A text with readings. Cape Town: Oxford University Press, pp. 20-34. 